\title{
Effect of Microbial Inoculants on Uptake of Nutrient Elements in Two Cultivars of Sunflower (Helianthus annuus L.) in Saline Soils
}

\author{
Mostafa SHIRMARDI'), Gholam Reza SAVAGHEBI'1), Kazem KHAVAZI²), Ali \\ AKBARZADEH ${ }^{1)}$, Mohsen FARAHBAKHSH ${ }^{1}$, Farhad REJALI' ${ }^{2}$, Abdolvahab SADAT ${ }^{1)}$ \\ 1) University of Tehran, University College of Agriculture and Natural Resources, Faculty of Agricultural \\ Engineering and Technology, Department of Soil Science, Karaj, 31587-77871, Iran; mos_shirmardi@yahoo. \\ com;savagheb@ut.ac.ir;aliakbarzadeh1236@yahoo.com;mfbakhsh@ut.ac.ir;av.sadat@gmail.com \\ 2) Soil and Water Research Institute, Tehran,14155-6185,Iran;kkhavazi@yahoo.com; frejali@yahoo.com
}

\begin{abstract}
A greenhouse experiment was conducted in order to evaluate the interactive effects of microbial inoculants on uptake of nutrient elements (N, P, K, Ca, Mg, Na, Cl, Fe, Zn, Cu, Mn) in two cultivars of sunflower. The trials were carried out on saline $\left(\mathrm{EC}=7.6 \mathrm{dS} \mathrm{m}^{-1}\right)$ calcareous soils taken from Eshtehard (Karaj) region of Iran. In a factorial trial and completely randomized design (CRD), three levels of arbuscular mycorrhizal inoculants (non inoculation, inoculation with Glomus etunicatum and Glomus intradices) and four levels of Pseudomonas fluorescens inoculants (non inoculation and inoculation with Pseudomonas fluorescens strains 4, 9, 12) in two cultivars of sunflower with four replications per treatments were applied. Results revealed that all of the treatments increased the $\mathrm{N}$ uptake in Euroflor cultivar. Moreover, in Euroflor cultivar, inoculation with Pseudomonas fluorescens strains 9 and co-inoculation of Pseudomonas fluorescens strains 4 and Glomus intradices made a significant different in phosphorous uptake, while did not make any significant change in the Master cultivar. However, bacterial and fungal treatments significantly $(P<0.05)$ increased uptake of micro nutrients such as Fe, $\mathrm{Zn}$ and $\mathrm{Mn}$.
\end{abstract}

Keywords: Arbuscular mycorrbiza, plant growth promoting rhizobacteria, salinity, sunflower

\section{Introduction}

Today accurate management of soils having salt problems, for achievement to maximum yield has received widespread attention throughout the world. Over than 1000 million hectare of the world's land are affected by the salt problems and these areas including about $7 \%$ of the total world's land. Also from 1.5 billion of agricultural lands throughout the world, about 77 million hectare $(5 \%$ from these areas) is extremely under influence of salt problems (Giri et al., 2007). Plants growing in these regions are seriously under salt stress and hence, due to harms received from this stress they never reach to their maximum growth and production. Chemical characteristics of soils affected by soluble salts which show their impact on plant growth are low activity of nutrient elements, high ratio of $\mathrm{Na}^{+}$/ $\mathrm{Ca}^{+2}, \mathrm{Na}^{+} / \mathrm{K}^{+}, \mathrm{Mg}^{2+} / \mathrm{Ca}^{+2}$ and $\mathrm{Cl}^{-} / \mathrm{NO}^{-3}$, nutrition malformation and reduction of overall growth and yield quality (Mirmahammadi-Meybodi and Ghareyazi, 2002). The presence of excessive $\mathrm{Na}^{+}$into the soil causes disruption in uptake and transportation of nutrient elements such as $\mathrm{Mg}^{2+}$ and $\mathrm{Ca}^{+2}$ by plants. Salt stress causes a variety of disruptions in plant nutrition and therefore, will provide adverse condition for plant development. These disruptions are usually because of negative effect of salts on uptake ability of nutrient elements, competitive behavior of elements for uptake, transportation and distribution of these elements to different parts of the plant. Also, salt stress some times leads to physiological non activity of one the essential nutrient element in the plant and therefore, the symptom of deficit will appear in the plant's tissues (Kafi and Damghani, 2000).

There are several methods for reducing of adverse effects of soil salinity. One of these methods is using of biological fertilizers. Due to many bioenvironmental problems caused by chemical fertilizers, these days many farmers tend to use biological fertilizers for achievement to sustainable agriculture. Plant growth-promoting rhizobacteria (PGPR) and arbuscular mycorrhizal (AM) fungi are representing two main groups of beneficial microorganisms of the rhizosphere which known as biological fertilizers (Russo et al., 2005). The beneficial effect of PGPRs as well as AM fungi on plants is well documented (Gamalero et al., 2003).

One of the major effects of salinity on plants is the ethylene accumulation in their roots which decrease root growth and finally reduce the yield of crops. PGPRs are able to produce ACC-deaminase in plants rhizosphere and they can consume pre-produced ethylene (ACC) and convert it to $\alpha$-ketobutyrate and ammonium, so they are 
58

able to reduce ethylenes level in plants and hence, increase their growth (Glick et al., 1998; Penrose and Glick, 2003). Mayak et al. (2004) evaluated the role of a PGPR (Achromobacter piechaudii) bacterium in resistance of tomato plant to salt stress in dry salty environments of Israel. This bacterium significantly increased the fresh and dry weights of tomato seedlings grown in the presence of up to 172 $\mathrm{mM} \mathrm{NaCl}$ salt. The bacterium reduced the production of ethylene by tomato seedlings which were otherwise stimulated when seedlings were challenged with increasing salt concentrations, but did not reduce the content of sodium. However, it slightly increased the uptake of phosphorous and potassium which may contribute in part to activation of processes involved in the alleviation of the effect of salt. Saravanakumar and Samiyappan (2007) reported that Pseudomonas Xuorescens strain TDK1 containing ACC deaminase activity enhanced the saline resistance in groundnut plants and increased yield as compared with that inoculated with Pseudomonas strains lacking ACC deaminase activity. Cheng et al. (2007) have also pointed out that ACC deaminase bacteria conferred salt tolerance onto plants by lowering the synthesis of salt-induced stress ethylene and promoted the growth of canola in saline environment. Nadeem et al. (2006a,b) have observed almost similar results in the case of maize growth under salt stress in response to inoculation with ACC deaminase PGPR. Similarly, Hamdia et al. (2004) studied the effect of a PGPR (Azospirillum brasilense) on uptake of elements in corn plants as grown in salty conditions. They reported that the $\mathrm{Na}^{+}$concentration in the root and above ground parts of corn plants decreased while the $\mathrm{Ca}^{2+}$ and $\mathrm{K}^{+}$concentration in these organs of plants inoculated by PGPR increased.

Decreasing of ion activity in soil solution and appearance of nutrition problems in plants is the other unfavorable effect of salinity. If AM fungi are used as a symbiosis participant in plants rhizosphere, plants achieve the beneficial effects of this relationship. AM fungi produce hypha networks on the surface of plants roots thus increase the volume of soil which is available for them, so existence of this network helps plants to take more water and nutrient elements. Also, AM fungi are known to increase plant tolerance to abiotic stress, in particular soil salinity. Yano-Melo et al. (2003) showed that inoculation of banana plants (Musa sp. cv. Pacovan) with specific AM fungi (Glomus isolates) reduced plant stress caused by soil salinization. Similarly, Copeman et al. (1996) reported that AM fungi can promote tomato plant growth through improvement of plant nutrition and production of osmoregulators in salty environments. Sannazzaro et al. (2007) investigated the involvement of Glomus intraradices in the regulation of plant growth, polyamines and proline levels of two Lotus glaber genotypes differing in salt tolerance, after longterm exposure to saline stress. They suggested that modulation of polyamine pools can be one of the mechanisms used by AM fungi to improve Lotus glaber adaptation to saline soils. Al-Karaki (2006) indicated that pre-inoculation of tomato transplants with AM fungi improved yield and can help alleviate deleterious effects of salt stress on crop yield. He showed that shoot contents of $\mathrm{P}, \mathrm{K}, \mathrm{Zn}, \mathrm{Cu}$, and Fe were higher in AM compared with nonAM plants grown under nonsaline and saline water conditions. In addition, shoot $\mathrm{Na}$ concentrations were lower in AM than nonAM plants grown under saline water conditions. Feng et al. (2002) showed that AM fungi are able to increase tolerance of maize plants to salt stress. They reported that mycorrhizal plants had higher electrolyte concentrations in roots and lower electrolyte leakage from roots than non-mycorrhizal plants under given $\mathrm{NaCl}$ and $\mathrm{P}$ levels. Sannazzaro et al. (2006) found that AM fungi (Glomus intraradices) improved growth of Lotus glaber plants under saline conditions. They showed that mycorrhizal plants had higher values of net growth, shoot/root and $\mathrm{K}^{+} / \mathrm{Na}^{+}$ ratios and protein concentrations than controls.

In many areas of Iran due to low precipitation and overexploitation of available water resources (e.g., ground water) often soils are saline. In addition, this salinity is mostly due to irrigation practices that bring salts to the soil surface where they can be toxic to crop plants. This salinity probably reduce plants uptake of nutrient elements from soil and hence, leads to reduction in crop growth and yield. Proper cropping techniques to run sustainable agriculture in the presence of irrigation water of poor quality (e.g., saline) becoming essential especially with limiting availability of fresh water for irrigation use (Al-Karaki, 2006). One of these cropping techniques is improvement of plant tolerance to saline condition by microbial inoculants. Therefore, this study carried out with objectives (a) to investigate the effect of PGPRs (Strains of Pseudomonas fluorescens) and AMF (Glomus etunicatum and Glomus intradices) on reducing salt stress and improvement of nutrition condition of sunflower plants, (b) to study the role of co-inoculation of sunflower plant by PGPRs and AMF in increasing uptake of nutrient elements and (c) to evaluate and compare the nutrition response of two cultivars of sunflower (Euroflor and Master) to microbial inoculation.

\section{Materials and methods}

\section{Plant selection}

One of the best characteristic of sunflower is its high aptitude to establishing of symbiosis with mycorrhizal fungi. This characteristic often can not observe easily in other plants. Therefore, sunflower may benefit from this symbiosis. This nature of sunflower along with its economic importance that introduce this plant as an industrial oilseed crop having main source of high quality of edible oil, were adequate reasons for selecting of this plant in present research. This study was carried out at greenhouse condition. Plastic pots having $22 \mathrm{~cm}$ height and $20 \mathrm{~cm}$ opening 
mouth diameter were selected for planting of sunflowers. The weight of each vacant pot was about $250 \mathrm{~g}$. Approximately $4 \mathrm{~kg}$ of air-dried soil passed through a $4.8 \mathrm{~mm}$ sieve was added to each plastic pot. Two cultivars of sunflower seeds (Euroflor and Master) were provided from institute of seed and seedling of Karaj for this research. Before sowing the seeds into the pots, the seeds that their shape was similar were selected and then, were kept in the trays containing javelle water $(2.5 \%)$ for 7 minute. Then the seeds were washed 6-7 times by distilled water and were held several days on the sterile papers inside the incubator for germination.

\section{Microbial inoculants}

Microbial inoculants including micorrhizal fungi (AMF) and bacteria (PGPR) were prepared from soil \& water research institute of Iran as powdery forms and separated boxes. The mycorrhizal inoculants including Glomus etunicatum and Glomus intradices were isolated from saline soils of Tabriz plane which located in northern Iran. The fungi population in these inoculants was about $1.6 \times 10^{4}$ fungus per $1 \mathrm{~g}$ soil. The bacterial inoculants were consisted of strains 4, 9, 12 of Pseudomonas fluorescens (Tab. 1).

Tab. 1. Some characteristics of bacteria used in this study

\begin{tabular}{cccc}
\hline Bacterium & $\begin{array}{c}\text { Activity of ACC } \\
\text { deaminase } \\
\left(\mu \text { moles }^{-1} \mathrm{~h}^{-1}\right)\end{array}$ & $\begin{array}{c}\text { Auxin } \\
\left(\mu \mathrm{m} \mathrm{m}^{-1}\right)\end{array}$ & $\begin{array}{c}\text { Bacterial } \\
\text { population } \\
\text { in inoculants } \\
\left(\mathrm{Cfu} \mathrm{ml}^{-1}\right)\end{array}$ \\
\hline $\begin{array}{c}\text { Pseudomonas fluorescence } \\
\text { strain 4 }\end{array}$ & 8.17 & 2.38 & $7.7 \times 10^{9}$ \\
$\begin{array}{c}\text { Pseudomonas fluorescence } \\
\text { strain 9 }\end{array}$ & 4.45 & 0.93 & $2.1 \times 10^{9}$ \\
$\begin{array}{c}\text { Pseudomonas fluorescence } \\
\text { strain 12 }\end{array}$ & 4.61 & 1.2 & $2.5 \times 10^{9}$ \\
\hline
\end{tabular}

\section{Cultural practices}

Before transferring the seedlings into the plastic pots, the soil was irrigated to the field capacity level. When the soil moisture was suitable for planting, according to treatment design, in each pot 4 small holes were shaped and then, $2 \mathrm{~g}$ fungi inoculants and $1 \mathrm{~g}$ bacterial inoculants were added to the inside of these holes. After that in these entire holes, one seedling of sunflower was planted and pots were irrigated at the level of field capacity on the basis of the weight of each pot. According to soil analysis, the essential elements as chemical fertilizers were added to the soils. Just the phosphorous applied at the half of its optimum level due to proper studding the effect of micorrhizal fungi. After suitable establishing of plants in the plastic pots, the number of plant was reduced to two plants in each pot by removing them. The air temperature inside the green- house was hold approximately fixed at $25^{\circ} \mathrm{C}$ during the growth stages of sunflower plants. Also, the period of sunshine was about 12 hours throughout the plant growth. Approximately 90 days after transplanting, the sunflower plants were cut form their bottom.

\section{Soil type}

It was needed a salty soil for the experiments. Therefore, a pre-sampling performed from different locations in Eshtehard (Karaj) region of Iran. After determining the salinity of these pre-samples, the best place was selected. The sampling spot is located between $35^{\circ}, 43^{\prime}$ in eastern latitude and $50^{\circ}, 18^{\prime}$ in northern longitude. Silage maize is the major feeder crop followed by alfalfa and wheat are the main cereal crop in this region. Due to the lack of animal manure, crop production is based on mineral NPK fertilizers. This area is also situated in a river alluvial plain and the soil of this region belongs to xeric haplocambids. The soil texture is loamy with an average $\mathrm{pH}$ of $7.8, \mathrm{EC}$ of $7.6 \mathrm{dS} \mathrm{m}{ }^{-1}$, organic matter $(\mathrm{OM})$ content of $0.5 \%, \mathrm{CaCO}_{3}$ content of $13.6 \%$, gypsum content of $3.1 \%$, total $\mathrm{N}$ content of 0.045 , saturation percentage (SP) of $37.3 \%$, sodium adsorption ratio (SAR) of 9.24, exchangeable sodium percentage (ESP) of $11 \%$ and cation exchange capacity (CEC) level of $16.9 \mathrm{meq}$ per $100 \mathrm{~g}$ of soil. The levels of soluble $\mathrm{Na}, \mathrm{Mg}, \mathrm{Ca}, \mathrm{K}, \mathrm{Cl}$ and $\mathrm{HCO}_{3}$ in the soil were 45.6, $10.0,39.7,14.1,46.5$ and 5.3 meq $^{1^{-1}}$ respectively. Also the level of $\mathrm{Fe}, \mathrm{Zn}, \mathrm{Cu}$ and $\mathrm{Mn}$ extracted by DTPA in the soil were $2.8,1.6,1.3$ and $10.0 \mathrm{mg} \mathrm{kg}^{-1}$, respectively.

\section{Plant analysis}

For measuring of different elements in plant tissues, the dry ashing method was used. In this method, the grinded plants were dried in the oven with the temperature of 70 ${ }^{\circ} \mathrm{C}$ for 48 hours. In the next stage $2 \mathrm{~g}$ of these dry matter that were tranfered into the ceramic vessels were subjected slowly to $450^{\circ} \mathrm{C}$ heat in the oven. The final product was a white ash. After cooling the white ashes in room temperature, $20 \mathrm{ml} \mathrm{1N} \mathrm{HCl}$ was added to each sample and followed by the sand bath for 30 minutes. Then the samples were elutriated in a $100 \mathrm{ml}$ volumetric balloon (Cottenie, 1980).

After providing the plant extracts, the concentration of $\mathrm{K}$ and $\mathrm{Na}$ was measures by flamephotometer apparatuses (ELE) directly in the volumetric balloons. Also, the concentration of $\mathrm{Ca}$ and $\mathrm{Mg}$ were measured by complexometery method and $\mathrm{Fe}, \mathrm{Zn}, \mathrm{Cu}$ and $\mathrm{Mn}$ were measured by atomic apparatus (Shimadzu AA6600) directly in the balloons. For measuring of plant phosphorus percentage, the yellow method was used. In this technique nitrovanado molybdate as an indicator was applied and the $\mathrm{P}$ concentration measured in the wave length of $430 \mathrm{~nm}$ using spectrophotometer apparatus (Shimadzu UV3100). The total plant $\mathrm{N}$ in the plant was measured using digestion 
60

method by the Kejeldahl apparatus (Cottenie, 1980). The percentage of $\mathrm{Cl}$ in plant tissues was measured by the Hipp and langdal (1971) method using a chlorometer apparatus (METEROHM-781). This apparatus has an ion selective electrode (ISE) and therefore, is able to measure the concentration of $\mathrm{Cl}$ in extracts directly. After measuring of element concentration (\% for macroelements and $\mathrm{mg} \mathrm{kg}^{-1}$ for microelements) in aerial parts (above ground organs) of the plant tissues, the rate of uptake $\left(\mathrm{mg} \mathrm{pot}^{-1}\right)$ for different elements was also calculated on the basis of plant dry matter.

\section{Experimental design and statistical analysis}

The analysis of variance (ANOVA) was carried out with randomized complete block design with sub split plot. Main plot were three levels of arbuscular mycorrhizal inoculants including non inoculation $\left(\mathrm{F}_{0}\right)$, inoculation with Glomus etunicatum $\left(\mathrm{F}_{1}\right)$ and Glomus intradices $\left(\mathrm{F}_{2}\right)$. Sub plot were four levels of Pseudomonas fuorescens inoculants including non inoculation $\left(\mathrm{B}_{0}\right)$, inoculation with Pseudomonas fluorescens strains $4\left(\mathrm{~B}_{0}\right)$, Pseudomonas fluorescens strains $9\left(\mathrm{~B}_{2}\right)$, Pseudomonas fluorescens strains $12\left(\mathrm{~B}_{3}\right)$. Sub sub plot were two cultivars of sunflower including Euroflor $\left(\mathrm{C}_{1}\right)$ and Master $\left(\mathrm{C}_{2}\right)$ (Tab. 2). The ANOVA was performed using SAS and Minitab softwares. Comparison of mean values was done using Duncan multiple range test by MSTATC software at $5 \%$ probability level.

\section{Results}

\section{Major effect offungus, bacterium and cultivar on uptake of elements}

The result of analysis of variance (ANOVA) for the major effect of fungus, bacterium and cultivar of sunflowers on uptake of macro elements showed that the fungus and cultivar inoculants had no significant effect on uptake of $\mathrm{N}$, while the effect of bacterium was significant $(p<0.01)$. Bacterium and cultivar had significant effect $(p<0.05)$ on uptake of $\mathrm{P}$ to above ground parts of the plants, while the fungus had not any influence. Fungus, cultivar and bacterium had significant effect on uptake of $\mathrm{K}$ by the plants.

Tab. 2. Different treatments

\begin{tabular}{ccc}
\hline & Treatments & \\
\hline \multirow{4}{*}{ Fungi } & Without fungus & $\left(\mathrm{F}_{0}\right)$ \\
& Glomus etunicatum & $\left(\mathrm{F}_{1}\right)$ \\
& Glomus intradices & $\left(\mathrm{F}_{2}\right)$ \\
& Without bacterium & $\left(\mathrm{B}_{0}\right)$ \\
\multirow{3}{*}{ Bacteria } & Pseudomonas fluorescence strain 4 & $\left(\mathrm{B}_{1}\right)$ \\
& Pseudomonas fluorescence strain 9 & $\left(\mathrm{B}_{2}\right)$ \\
& Pseudomonas fluorescence strain 12 & $\left(\mathrm{B}_{3}\right)$ \\
Cultivar of & Euroflor & $\left(\mathrm{C}_{1}\right)$ \\
sunflower & Master & $\left(\mathrm{C}_{2}\right)$ \\
\hline
\end{tabular}

Fungus and bacterium had significant effect on uptake of $\mathrm{Ca}$, whereas the cultivar had not any influence. In the case of $\mathrm{Mg}$, the bacterium and cultivar had significant effect on its uptake by the plants $(p<0.01)$, while the fungi had no influence (Tab. 3). The comparison of mean indicated that none of the fungus inoculants as well as sunflower cultivars had no significant effect on uptake of $\mathrm{N}$ to the above ground parts of the plants, whereas the bacteria inoculants of $\mathrm{B}_{1}$ and $\mathrm{B}_{3}$ significantly $(p<0.05)$ increased and decreased the $\mathrm{N}$ uptake by plants, respectively. Fungi treatments had not any effect on uptake of $P$. Also between the bacteria inoculants, the $\mathrm{B}_{1}$ treatment had significant effect on enhancing the $\mathrm{P}$ uptake compared with the control treatment. The lowest uptakes were related to control $\left(\mathrm{B}_{0}\right)$ and $\mathrm{B}_{1}$ treatments. In addition the cultivar of Euroflor $\left(C_{1}\right)$ had higher $P$ uptake compared with the Master $\left(C_{2}\right)$. Addition of treatment of $F_{1}$ had a significant decreasing effect $(p<0.05)$ on uptake of $\mathrm{K}$ between other fungi treatment. Between bacteria inoculants, the $B_{3}$ treatment had a significant effect $(p<0.05)$ on decreasing the $\mathrm{K}$ uptake compared with its control treatment. In addition, between the cultivars of sunflower, the Master $\left(\mathrm{C}_{2}\right)$ had higher uptake of $\mathrm{K}$ than to the Euroflor $\left(\mathrm{C}_{1}\right)$. The comparison of mean for fungi treatments showed that the most level of Ca uptake was related to control treatment. Therefore, the fungi inoculants did not increased the $\mathrm{Ca}$ uptake by the plants and even inversely reduced the Ca uptake. Between the bacteria treatments, the $\mathrm{B}_{3}$ had the highest level of $\mathrm{Ca}$ uptake and had significant difference $(p<0.05)$ with the $B_{1}$ and $B_{2}$ treatments. Moreover, application of $B_{1}$ treatment reduced significantly uptake of $\mathrm{Mg}$ ( Tab. 4).

The result of ANOVA for the major effect of fungus, bacterium and cultivar of sunflowers on uptake of micro elements $(\mathrm{Fe}, \mathrm{Zn}, \mathrm{Cu}$, and $\mathrm{Mn})$ and elements of $\mathrm{Na}$ and $\mathrm{Cl}$ showed the cultivar had significant effect $(p<0.01)$ on uptake of all of these elements (micro and $\mathrm{Na}$ and $\mathrm{Cl}$ ). The effect of bacterium and fungus was significant on uptake of the entire micro element except $\mathrm{Fe}$ and $\mathrm{Cu}$, respectively. Also, the fungus had no any significant effect of uptake of $\mathrm{Cl}$ (Tab. 3). The result of comparison of mean for the major effect of fungus, bacterium and cultivar of sunflowers on uptake of micro elements and elements of $\mathrm{Na}$ and $\mathrm{Cl}$ showed that between the fungi treatment, the most uptake of $\mathrm{Na}$ was observed in the $\mathrm{F}_{1}$ treatment. Application of $\mathrm{F}_{2}$ treatment had significant decreasing effect $(p<0.05)$ of uptake of Fe. The most and least levels of $\mathrm{Zn}$ uptake was related to $F_{2}$ and $F_{1}$ treatments, respectively and there was no significant difference between $\mathrm{F}_{0}$ and $\mathrm{F}_{1}$ treatments. Also, using of $\mathrm{F}_{1}$ treatment significantly $(p<0.05)$ reduced the uptake of $\mathrm{Mn}$ compared with the control $\left(\mathrm{F}_{0}\right)$ treatment and the most level of Mn uptake was observed in the $\mathrm{F}_{0}$ treatment (Tab. 4). In addition, all of the three bacterial inoculants $\left(B_{1}, B_{2}\right.$ and $\left.B_{3}\right)$ had significant effect on increasing $\mathrm{Na}$ uptake by plants compared with the control treatment $\left(\mathrm{B}_{0}\right)$. The treatment of $\mathrm{B}_{3}$ had the lowest level of $\mathrm{Cl}$ uptake between other treatments and had significant dif- 
Tab. 3. ANOVA for uptake of macro and micro elements and elements of $\mathrm{Na}$ and $\mathrm{Cl}$

\begin{tabular}{|c|c|c|c|c|c|c|c|}
\hline \multirow{2}{*}{ S.O.V. } & \multirow{2}{*}{ df. } & \multicolumn{6}{|c|}{ Mean square } \\
\hline & & $\mathrm{N}$ & $\mathrm{P}$ & $\mathrm{K}$ & & $\mathrm{Ca}$ & $\mathrm{Mg}$ \\
\hline Fungus $(\mathrm{F})$ & 2 & $395.821 \mathrm{~ns}$ & $11.076 \mathrm{~ns}$ & $44220.618^{* *}$ & & $2195.906^{* *}$ & $39.65 \mathrm{~ns}$ \\
\hline Bacterium (B) & 3 & $3096.918^{* *}$ & $38.262^{*}$ & $29221.314^{*}$ & & $787.683^{*}$ & $393.328^{* *}$ \\
\hline Cultivar (C) & 1 & $24.837 \mathrm{~ns}$ & $71.826^{*}$ & $189126.616^{* *}$ & & $406.722 \mathrm{~ns}$ & $6649.678^{* *}$ \\
\hline $\mathrm{F} \times \mathrm{B}$ & 6 & 403.486ns & $10.299 \mathrm{~ns}$ & $7958.785 \mathrm{~ns}$ & & $2073.474^{* *}$ & $871.125^{* *}$ \\
\hline $\mathrm{F} \times \mathrm{C}$ & 2 & $269.628 \mathrm{~ns}$ & $28.944 \mathrm{~ns}$ & $4907.554 \mathrm{~ns}$ & & $177.344 \mathrm{~ns}$ & $46.879 \mathrm{~ns}$ \\
\hline $\mathrm{B} \times \mathrm{C}$ & 3 & $2701.637^{* *}$ & $18.696 \mathrm{~ns}$ & $62835.263^{* *}$ & & 471.306ns & $826.532^{* *}$ \\
\hline Error & 72 & $499.862 \mathrm{~ns}$ & $12.244 \mathrm{~ns}$ & $7654.433 \mathrm{~ns}$ & & $278.88 \mathrm{~ns}$ & $73.582 \mathrm{~ns}$ \\
\hline \multirow{2}{*}{ S.O.V. } & \multirow{2}{*}{ df. } & \multicolumn{6}{|c|}{ Mean square } \\
\hline & & $\mathrm{Na}$ & $\mathrm{Cl}$ & $\mathrm{Fe}$ & $\mathrm{Zn}$ & $\mathrm{Cu}$ & $\mathrm{Mn}$ \\
\hline Fungus $(\mathrm{F})$ & 2 & $97.141^{* *}$ & $2791.874 \mathrm{~ns}$ & $13.342^{* *}$ & $0.96^{*}$ & $0.087 \mathrm{~ns}$ & $3.219^{* *}$ \\
\hline Bacterium (B) & 3 & $107.528^{* *}$ & $20553.466^{* *}$ & $6.65 \mathrm{~ns}$ & $0.96^{*}$ & $1.1^{* *}$ & $2.328^{* *}$ \\
\hline Cultivar (C) & 1 & $778.148^{* *}$ & $195877.466^{* *}$ & $32.83^{* *}$ & $5.175^{* *}$ & $2.908^{* *}$ & $27.8^{* *}$ \\
\hline $\mathrm{F} \times \mathrm{B}$ & 6 & $42.309^{*}$ & $7507.172^{*}$ & $8.718^{* *}$ & $0.499 \mathrm{~ns}$ & $0.243 \mathrm{~ns}$ & $0.604 \mathrm{~ns}$ \\
\hline $\mathrm{F} \times \mathrm{C}$ & 2 & $18.233 \mathrm{~ns}$ & $9995.483^{*}$ & $0.222 \mathrm{~ns}$ & $0.2 \operatorname{lns}$ & $0.002 \mathrm{~ns}$ & $0.454 \mathrm{~ns}$ \\
\hline $\mathrm{B} \times \mathrm{C}$ & 3 & $63.479^{* *}$ & $33481.074^{* *}$ & $6.628 \mathrm{~ns}$ & $0.533 \mathrm{~ns}$ & $1.602^{* *}$ & $2.65^{* *}$ \\
\hline Error & 72 & $14.36 \mathrm{~ns}$ & $2476.343 \mathrm{~ns}$ & $2.531 \mathrm{~ns}$ & $0.279 \mathrm{~ns}$ & $0.269 \mathrm{~ns}$ & $0.521 \mathrm{~ns}$ \\
\hline
\end{tabular}

" and " significant at 1 and 5\%, respectively; ${ }^{\text {ns }}$ non significant

ference $(p<0.05)$ with control treatment $\left(B_{0}\right)$. The $B_{2}$ and $\mathrm{B}_{3}$ treatments showed the maximum and minimum level of Fe uptake by plants but none of them had no significant difference with the control treatment $\left(\mathrm{B}_{0}\right)$. All of the three bacterial inoculants $\left(B_{1}, B_{2}\right.$ and $\left.B_{3}\right)$ were increased $Z n$ and
$\mathrm{Cu}$ uptake whereas, application of bacterial inoculants significantly decreased uptake of $\mathrm{Mn}$ by the plants. So that, the most levels of Mn uptake was related to $B_{0}$ and $B_{1}$ treatments and the least was related to $\mathrm{B}_{3}$ treatment. Also, Master cultivar $\left(\mathrm{C}_{2}\right)$ of sunflower had higher uptake of $\mathrm{Na}$

Tab. 4. The comparison of mean for the major effect of different levels of fungus, bacterium and cultivar on uptake of macro and micro elements and elements of $\mathrm{Na}$ and $\mathrm{Cl}\left(\mathrm{mg} \mathrm{pot}^{-1}\right)$

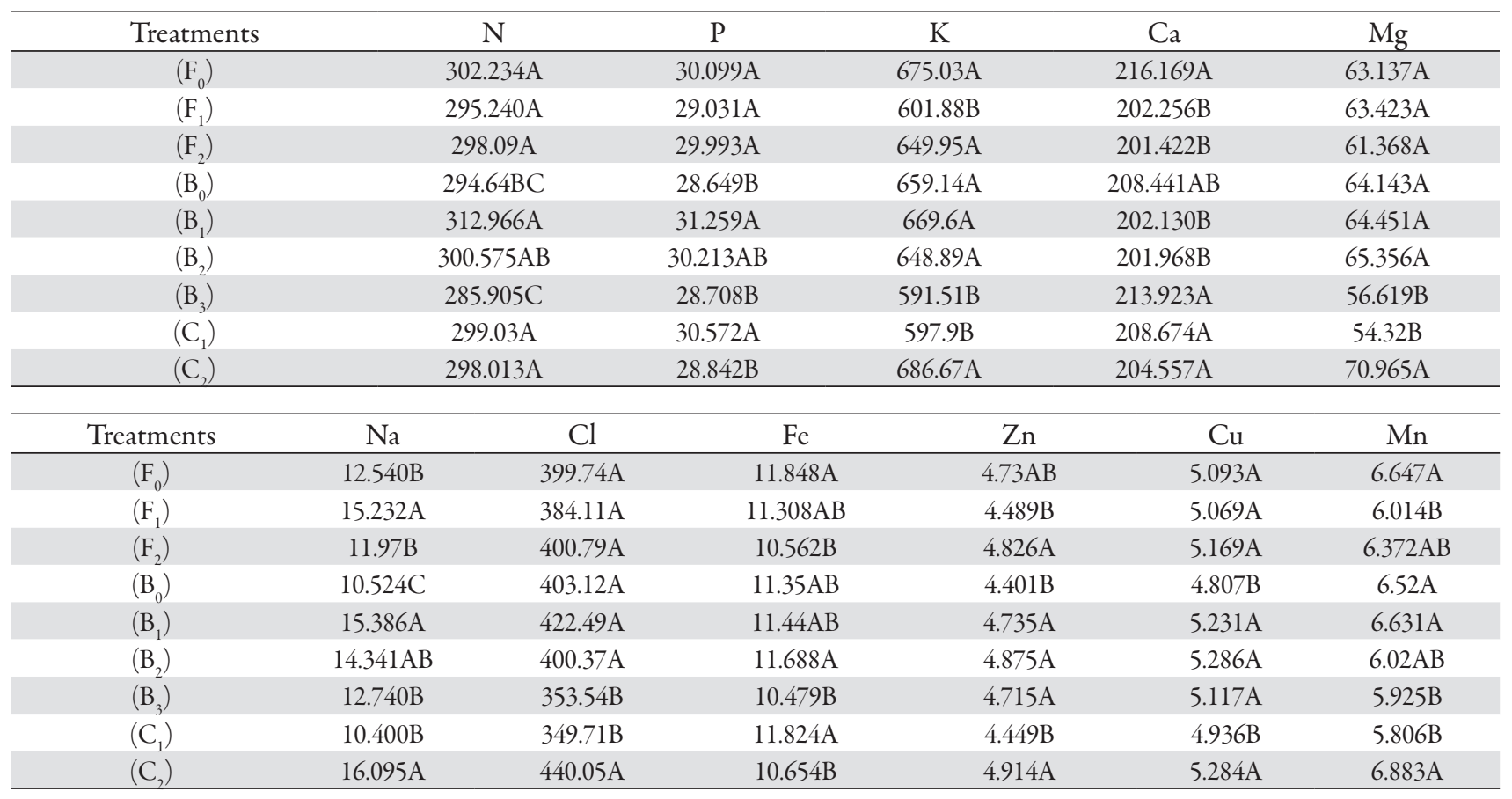

Means, in each column, with at least one similar letters are not significantly different at the $5 \%$ probability level using Duncan multiple range test 
Tab. 5. The comparison of mean for the interaction effect between fungus and bacterium on uptake of macro and micro elements and elements of $\mathrm{Na}$ and $\mathrm{Cl}\left(\mathrm{mg} \mathrm{pot}^{-1}\right)$

\begin{tabular}{|c|c|c|c|c|c|c|}
\hline Treatments & & $\mathrm{N}$ & $\mathrm{P}$ & $\mathrm{K}$ & $\mathrm{Ca}$ & $\mathrm{Mg}$ \\
\hline$\left(\mathrm{F}_{0} \mathrm{~B}_{0}\right)$ & & $294.1 \mathrm{ABCD}$ & $27.72 \mathrm{AB}$ & $680.1 \mathrm{ABC}$ & $210.7 \mathrm{BC}$ & $71.87 \mathrm{AB}$ \\
\hline$\left(\mathrm{F}_{0} \mathrm{~B}_{1}\right)$ & & $316.4 \mathrm{~A}$ & $31.17 \mathrm{AB}$ & $724.4 \mathrm{~A}$ & 212.9ABC & $67.25 B C$ \\
\hline$\left(\mathrm{F}_{0} \mathrm{~B}_{2}\right)$ & & $309 / 4 \mathrm{ABC}$ & $31.64 \mathrm{~A}$ & $662.1 \mathrm{ABC}$ & $219.9 \mathrm{AB}$ & $64.07 \mathrm{BC}$ \\
\hline$\left(\mathrm{F}_{0} \mathrm{~B}_{3}\right)$ & & $289.0 \mathrm{BCD}$ & $29.87 \mathrm{AB}$ & $633.5 \mathrm{ABC}$ & $221.1 \mathrm{AB}$ & $49.36 \mathrm{E}$ \\
\hline$\left(\mathrm{F}_{1} \mathrm{~B}_{0}\right)$ & & $289.8 \mathrm{BCD}$ & $28.02 \mathrm{AB}$ & $595.9 \mathrm{CD}$ & $190.8 \mathrm{D}$ & $51.30 \mathrm{DE}$ \\
\hline$\left(\mathrm{F}_{1} \mathrm{~B}_{1}\right)$ & & $307.5 \mathrm{ABC}$ & $31.63 \mathrm{~A}$ & 625.9ABCD & $197.6 \mathrm{CD}$ & $59.86 \mathrm{CD}$ \\
\hline$\left(\mathrm{F}_{1} \mathrm{~B}_{2}\right)$ & & $304.1 \mathrm{ABCD}$ & $29.13 \mathrm{AB}$ & $651.7 \mathrm{ABC}$ & $190.3 \mathrm{D}$ & $77.03 \mathrm{~A}$ \\
\hline$\left(\mathrm{F}_{1} \mathrm{~B}_{3}\right)$ & & $279.6 \mathrm{D}$ & $27.34 \mathrm{~B}$ & 533.9D & $230.3 \mathrm{~A}$ & $65.50 \mathrm{BC}$ \\
\hline$\left(\mathrm{F}_{2} \mathrm{~B}_{0}\right)$ & & $300.0 \mathrm{ABCD}$ & $30.21 \mathrm{AB}$ & 701.4AB & $223.8 \mathrm{AB}$ & $69.27 \mathrm{ABC}$ \\
\hline$\left(\mathrm{F}_{2} \mathrm{~B}_{1}\right)$ & & $315.0 \mathrm{AB}$ & $30.98 \mathrm{AB}$ & $658.5 \mathrm{ABC}$ & 195.9CD & $66.24 \mathrm{BC}$ \\
\hline$\left(\mathrm{F}_{2} \mathrm{~B}_{2}\right)$ & & $288.2 \mathrm{CD}$ & $29.87 \mathrm{AB}$ & $632.8 \mathrm{ABC}$ & $195.7 \mathrm{CD}$ & $54.96 \mathrm{DE}$ \\
\hline$\left(\mathrm{F}_{2} \mathrm{~B}_{3}\right)$ & & 289.1BCD & $28.91 \mathrm{AB}$ & 607.1BCD & 190.3D & $55.00 \mathrm{DE}$ \\
\hline Treatments & $\mathrm{Na}$ & $\mathrm{Cl}$ & $\mathrm{Fe}$ & $\mathrm{Zn}$ & $\mathrm{Cu}$ & $\mathrm{Mn}$ \\
\hline$\left(\mathrm{F}_{0} \mathrm{~B}_{0}\right)$ & $8.139 \mathrm{~F}$ & $379.2 \mathrm{BCD}$ & $11.09 \mathrm{AB}$ & $4.434 \mathrm{BCD}$ & $4.680 \mathrm{C}$ & $6.766 \mathrm{AB}$ \\
\hline$\left(\mathrm{F}_{0} \mathrm{~B}_{1}\right)$ & $17.11 \mathrm{AB}$ & $429.9 \mathrm{AB}$ & $12.34 \mathrm{~A}$ & $5.033 \mathrm{AB}$ & $5.405 \mathrm{~A}$ & $6.910 \mathrm{~A}$ \\
\hline$\left(\mathrm{F}_{0} \mathrm{~B}_{2}\right)$ & 14.00ABCD & 418.1ABC & $12.25 \mathrm{~A}$ & $4.880 \mathrm{ABC}$ & $5.336 \mathrm{~A}$ & $6.768 \mathrm{AB}$ \\
\hline$\left(\mathrm{F}_{0} \mathrm{~B}_{3}\right)$ & 10.91DEF & $371.8 \mathrm{CD}$ & $11.71 \mathrm{AB}$ & $4.573 \mathrm{BCD}$ & 4.950ABC & 6.144ABCD \\
\hline$\left(\mathrm{F}_{1} \mathrm{~B}_{0}\right)$ & $12.37 \mathrm{CDE}$ & $381.3 \mathrm{BCD}$ & $10.67 \mathrm{AB}$ & $4.146 \mathrm{D}$ & $4.720 \mathrm{BC}$ & $5.983 \mathrm{BCD}$ \\
\hline$\left(\mathrm{F}_{1} \mathrm{~B}_{1}\right)$ & 15.00ABCD & 396.6ABCD & $11.20 \mathrm{AB}$ & $4.516 \mathrm{BCD}$ & 5.191ABC & 6.361ABC \\
\hline$\left(\mathrm{F}_{1} \mathrm{~B}_{2}\right)$ & $15.86 \mathrm{ABC}$ & 415.4ABC & $12.49 \mathrm{~A}$ & $4.911 \mathrm{ABC}$ & $5.300 \mathrm{AB}$ & 6.233ABCD \\
\hline$\left(\mathrm{F}_{1} \mathrm{~B}_{3}\right)$ & $17.71 \mathrm{~A}$ & 343.1D & $10.88 \mathrm{AB}$ & $4.384 \mathrm{CD}$ & $5.065 \mathrm{ABC}$ & 5.481D \\
\hline$\left(\mathrm{F}_{2} \mathrm{~B}_{0}\right)$ & 11.07DEF & $448.9 \mathrm{~A}$ & $12.29 \mathrm{~A}$ & $4.624 \mathrm{BCD}$ & $5.021 \mathrm{ABC}$ & $6.813 \mathrm{AB}$ \\
\hline$\left(\mathrm{F}_{2} \mathrm{~B}_{1}\right)$ & 14.05ABCD & $441.0 \mathrm{~A}$ & $10.78 \mathrm{AB}$ & $4.658 \mathrm{ABCD}$ & $5.098 \mathrm{ABC}$ & $6.621 \mathrm{ABC}$ \\
\hline$\left(\mathrm{F}_{2} \mathrm{~B}_{2}\right)$ & 13.16BCDE & $367.6 \mathrm{CD}$ & $10.32 \mathrm{BC}$ & $4.834 \mathrm{ABC}$ & $5.223 \mathrm{ABC}$ & $5.908 \mathrm{CD}$ \\
\hline$\left(\mathrm{F}_{2} \mathrm{~B}_{3}\right)$ & $9.602 \mathrm{EF}$ & $345.7 \mathrm{D}$ & $8.855 \mathrm{C}$ & $5.188 \mathrm{~A}$ & $5.335 \mathrm{~A}$ & 6.149ABCD \\
\hline
\end{tabular}

Means, in each column, with at least one similar letters are not significantly different at the $5 \%$ probability level using Duncan multiple range test

and $\mathrm{Cl}$ than to the Euroflor cultivar $\left(\mathrm{C}_{1}\right)$. This result also was observed for all of the microelements except Fe hence, the $\mathrm{C}_{1}$ treatment just had higher Fe uptake compared with the $\mathrm{C}_{2}$ treatment (Tab. 4).

\section{Interaction effect between fungus and bacterium $(F \times B)$}

The result of ANOVA (Tab. 3) showed that the interaction effect between fungus and bacterium $(\mathrm{F} \times \mathrm{B})$ had no any significant effect on $\mathrm{N}, \mathrm{P}$ and $\mathrm{K}$ uptake by the plants while this interaction $(\mathrm{F} \times \mathrm{B})$ had significant effect $(p<$ 0.01 ) on uptake of $\mathrm{Ca}$ and $\mathrm{Mg}$. The comparison of mean for the interaction effect between fungus and bacterium $(\mathrm{F} \times \mathrm{B})$ on uptake of macro elements showed the $\mathrm{F}_{0} \mathrm{~B}_{1}$ and $\mathrm{F}_{1} \mathrm{~B}_{3}$ treatments contained the maximum and minimum levels of $\mathrm{N}$ uptake but, none of these treatments had no significant differences with the control treatment $\left(\mathrm{F}_{0} \mathrm{~B}_{0}\right)$. At the level of $F_{0}$, application of $B_{1}$ and $B_{2}$ inoculants led to partial enhancement in $\mathrm{N}$ uptake. At the levels of $\mathrm{F}_{1}$ and $\mathrm{F}_{2}$, none of the bacterial inoculants $\left(\mathrm{B}_{1}, \mathrm{~B}_{2}\right.$ and $\left.\mathrm{B}_{3}\right)$ had any significant differences. In all of the $\mathrm{F} \times \mathrm{B}$ treatments except $F_{1} B_{3}$, the level of $\mathrm{P}$ uptake by the plants increased. In addition, the maximum and minimum levels of $\mathrm{K}$ uptake were related to treatments of $\mathrm{F}_{0} \mathrm{~B}_{1}$ and $\mathrm{F}_{1} \mathrm{~B}_{3}$, respectively. The $\mathrm{F}_{1} \mathrm{~B}_{3}$ treatment had the most level of Ca uptake between other treatments. At the levels of $F_{0}$, application all of the bacterial inoculants $\left(\mathrm{B}_{1}, \mathrm{~B}_{2}\right.$ and $\left.\mathrm{B}_{3}\right)$ insignificantly increased $\mathrm{Ca}$ uptake, while at $\mathrm{F}_{2}$ all of the bacterial inoculants significantly reduced $\mathrm{Ca}$ uptake. In associated with Mg uptake, the comparison of mean showed that the $\mathrm{F}_{0} \mathrm{~B}_{3}$, $\mathrm{F}_{1} \mathrm{~B}_{0}, \mathrm{~F}_{2} \mathrm{~B}_{2}$ and $\mathrm{F}_{2} \mathrm{~B}_{3}$ treatments had significant decrease compared with the control treatment $\left(\mathrm{F}_{0} \mathrm{~B}_{0}\right)$ (Tab. 5).

The result of ANOVA for interaction effect between fungus and bacterium $(\mathrm{F} \times \mathrm{B})$ in uptake of micro elements and elements of $\mathrm{Na}$ and $\mathrm{Cl}$ showed that this interaction had significant effect on $\mathrm{Na}, \mathrm{Cl}$ and $\mathrm{Fe}$ uptake, whereas this interaction had no significant effect on $\mathrm{Zn}, \mathrm{Cu}$ and Mn uptake (Tab. 3). The comparison of mean for the interaction effect between fungus and bacterium $(\mathrm{F} \times \mathrm{B})$ on uptake of micro elements and elements of $\mathrm{Na}$ and $\mathrm{Cl}$ showed that all the treatments except $\mathrm{F}_{0} \mathrm{~B}_{3}, \mathrm{~F}_{2} \mathrm{~B}_{0}$ and $\mathrm{F}_{2} \mathrm{~B}_{3}$ increased significantly $(p<0.05) \mathrm{Na}$ uptake by the plants compared with the control treatment $\left(\mathrm{F}_{0} \mathrm{~B}_{0}\right)$. The $\mathrm{F}_{2} \mathrm{~B}_{0}$ and $\mathrm{F}_{2} \mathrm{~B}_{1}$ treatments also significantly increased $\mathrm{Cl}$ uptake. The most and the least level of $\mathrm{Cl}$ uptake were related to $\mathrm{F}_{1} \mathrm{~B}_{3}$ and $\mathrm{F}_{2} \mathrm{~B}_{3}$, respectively. The results of comparison of 
mean demonstrated that the $\mathrm{F}_{2} \mathrm{~B}_{3}$ treatment reduced significantly Fe uptake than to the control $\left(\mathrm{F}_{0} \mathrm{~B}_{0}\right)$ treatment. For the $\mathrm{Zn}$, the treatments of $\mathrm{F}_{1} \mathrm{~B}_{2}$ and $\mathrm{F}_{2} \mathrm{~B}_{3}$ significantly $(p<0.05)$ increased its uptake. In addition, the treatments of $\mathrm{F}_{0} \mathrm{~B}_{1}, \mathrm{~F}_{0} \mathrm{~B}_{2}, \mathrm{~F}_{1} \mathrm{~B}_{2}$ and $\mathrm{F}_{2} \mathrm{~B}_{3}$ significantly increased $\mathrm{Cu}$ uptake compared with the control $\left(\mathrm{F}_{0} \mathrm{~B}_{0}\right)$ treatment. For $\mathrm{Mn}$, just the $\mathrm{F}_{1} \mathrm{~B}_{3}$ and $\mathrm{F}_{2} \mathrm{~B}_{2}$ treatments decreased significantly its uptake compared with the control treatment (Tab. 5).

Interaction effect between fungus and cultivar $(F \times C)$; bacterium and cultivar $(B \times C)$

The result of ANOVA indicated that the interaction effect between fungus and cultivar $(\mathrm{F} \times \mathrm{C})$ had no significant effect on uptake of none of the macro elements $(\mathrm{N}$, $\mathrm{P}, \mathrm{K}, \mathrm{Ca}$ and $\mathrm{Mg}$ ), while the interaction effect between bacterium and cultivar $(\mathrm{B} \times \mathrm{C})$ had significant effect $(p<$ 0.01 ) on all of the macro elements except $\mathrm{P}$ and $\mathrm{Ca}$ (Tab. 3 ). The comparison of mean showed that none of the FC treatments had any significant differences in $\mathrm{N}, \mathrm{P}$ uptake. The treatment of $\mathrm{F}_{0} \mathrm{C}_{2}$ had more $\mathrm{K}$ and $\mathrm{Mg}$ uptake than to the $\mathrm{F}_{0} \mathrm{C}_{1}$ treatment and application of $\mathrm{F}_{1} \mathrm{C}_{2}$ treatment significantly decreased $\mathrm{K}$ uptake by the plants. Similarly, the treatments of $\mathrm{F}_{1} \mathrm{C}_{1}$ and $\mathrm{F}_{2} \mathrm{C}_{1}$ significantly decreased Ca uptake (Tab. 6). Furthermore, the $\mathrm{B}_{0} \mathrm{C}_{2}$ treatment had more $\mathrm{N}, \mathrm{P}, \mathrm{K}$ and $\mathrm{Mg}$ uptake than to the $\mathrm{B}_{0} \mathrm{C}_{1}$ treatment. However, this increasing uptake level in $\mathrm{B}_{0} \mathrm{C}_{2}$ treatment for $\mathrm{P}$ was not significant. Also, $\mathrm{B}_{0} \mathrm{C}_{2}$ treatment had lower Ca uptake compared with the $\mathrm{B}_{0} \mathrm{C}_{1}^{2}$ treatment. The $\mathrm{B}_{1} \mathrm{C}_{1}$ and $\mathrm{B}_{2} \mathrm{C}_{1}$ treatments significantly increased $\mathrm{N}, \mathrm{P}$ and $\mathrm{Mg}$ uptake by the plants but, $\mathrm{B}_{3} \mathrm{C}_{2}$ treatment significantly decreased the $\mathrm{N}$ uptake. Application of $\mathrm{B}_{2} \mathrm{C}_{2}$ and $\mathrm{B}_{3} \mathrm{C}_{2}$ treatments significantly decreased $\mathrm{K}$ uptake. The $\mathrm{B}_{1} \mathrm{C}_{1}$ and
$\mathrm{B}_{2} \mathrm{C}_{1}$ treatments significantly reduced Ca uptake by the plants (Tab. 7).

The result of ANOVA for interaction effect between fungus and cultivar $(\mathrm{F} \times \mathrm{C})$ did not show significant effect on uptake of none of the micro elements $(\mathrm{Fe}, \mathrm{Zn}, \mathrm{Cu}$ and $\mathrm{Mn}$ ) as well as $\mathrm{Na}$, but this interaction had significant effect $(p<0.05)$ on $\mathrm{Cl}$ uptake. In addition, the interaction effect between bacterium and cultivar $(B \times C)$ had significant effect $(p<0.01)$ on $\mathrm{Na}$ and $\mathrm{Cl}$ uptake as well as all of the micro elements except $\mathrm{Fe}$ and $\mathrm{Zn}$ (Tab. 3). The comparison of mean showed that the treatment of $\mathrm{F}_{0} \mathrm{C}_{2}$ had higher $\mathrm{Na}, \mathrm{Cl}$ and $\mathrm{Mn}$ uptake compared with the $\mathrm{F}_{0} \mathrm{C}_{1}^{2}$ treatment. However with respecting to the $\mathrm{Fe}, \mathrm{Zn}$ and $\mathrm{Cu}$ uptake, there were no significant differences between two treatments. In addition, the treatment of $\mathrm{F}_{1} \mathrm{C}_{1}$ significantly increased and decreased the $\mathrm{Na}$ and both $\mathrm{Zn}$ and $\mathrm{Mn}$ uptake respectively compared with its control $\left(\mathrm{F}_{0} \mathrm{C}_{1}\right)$ treatment. The treatment of $\mathrm{F}_{2} \mathrm{C}_{1}$ just significantly decreased the Fe uptake and two treatments of $\mathrm{F}_{1} \mathrm{C}_{2}$ and $\mathrm{F}_{2} \mathrm{C}_{2}$ also significantly decreased the $\mathrm{Cl}$ and $\mathrm{Fe}$ uptake respectively (Tab. 6). Furthermore, the treatment of $\mathrm{B}_{0} \mathrm{C}_{2}$ had higher $\mathrm{Na}, \mathrm{Cl}, \mathrm{Zn}, \mathrm{Cu}, \mathrm{Mn}$ uptake compared with the $\mathrm{B}_{0} \mathrm{C}_{1}$ treatment. Moreover, with respecting to Fe uptake there was no significant differences between these two treatments. The treatment of $\mathrm{B}_{2} \mathrm{C}_{1}$ significantly enhanced the $\mathrm{Na}, \mathrm{Cl}$ and Fe uptake compared with its control $\left(\mathrm{B}_{0} \mathrm{C}_{1}\right)$ treatment. A similar result was observed for the $\mathrm{Cl}$ and $\mathrm{Mn}$ uptake by the $\mathrm{B}_{1} \mathrm{C}_{1}$ treatment. Moreover, two treatments of $\mathrm{B}_{1} \mathrm{C}_{2}$ and $\mathrm{B}_{2} \mathrm{C}_{2}$ significantly increased the Na uptake compared with their control $\left(\mathrm{B}_{0} \mathrm{C}_{2}\right)$ treatment. The treatments of $\mathrm{B}_{2} \mathrm{C}_{2}$ and $\mathrm{B}_{3} \mathrm{C}_{2}$ significantly reduced the $\mathrm{Cl}$ and $\mathrm{Mn}$ uptake compared with their control $\left(\mathrm{B}_{0} \mathrm{C}_{2}\right)$ treatment. At the level of $\mathrm{C}_{1}$ all of the bacterial inoculants $\left(\mathrm{B}_{1} \mathrm{C}_{1}, \mathrm{~B}_{2} \mathrm{C}_{1}\right.$ and

Tab. 6. The comparison of mean for the interaction effect between fungus and cultivar on uptake of macro and micro elements and elements of $\mathrm{Na}$ and $\mathrm{Cl}\left(\mathrm{mg} \mathrm{pot}^{-1}\right)$

\begin{tabular}{|c|c|c|c|c|c|c|}
\hline Treatments & & $\mathrm{N}$ & $\mathrm{P}$ & $\mathrm{K}$ & $\mathrm{Ca}$ & $\mathrm{Mg}$ \\
\hline$\left(\mathrm{F}_{0} \mathrm{C}_{1}\right)$ & & $299.4 \mathrm{~A}$ & $30.94 \mathrm{AB}$ & $617.7 \mathrm{BC}$ & $220.9 \mathrm{~A}$ & $53.45 \mathrm{~B}$ \\
\hline$\left(\mathrm{F}_{0} \mathrm{C}_{2}\right)$ & & $305.1 \mathrm{~A}$ & $29.25 \mathrm{ABC}$ & $732.4 \mathrm{~A}$ & $211.4 \mathrm{AB}$ & $72.82 \mathrm{~A}$ \\
\hline$\left(\mathrm{F}_{1} \mathrm{C}_{1}\right)$ & & $297.6 \mathrm{~A}$ & $28.96 \mathrm{BC}$ & $558.7 \mathrm{C}$ & 203.4B & $56.06 \mathrm{~B}$ \\
\hline$\left(\mathrm{F}_{1} \mathrm{C}_{2}\right)$ & & $292.9 \mathrm{~A}$ & $29.11 \mathrm{BC}$ & $645.1 \mathrm{~B}$ & 201.1B & $70.79 \mathrm{~A}$ \\
\hline$\left(\mathrm{F}_{2} \mathrm{C}_{1}\right)$ & & $300.1 \mathrm{~A}$ & $31.82 \mathrm{~A}$ & $617.3 \mathrm{BC}$ & $201.7 \mathrm{~B}$ & $53.45 \mathrm{~B}$ \\
\hline$\left(\mathrm{F}_{2} \mathrm{C}_{2}\right)$ & & $296.1 \mathrm{~A}$ & $28.17 \mathrm{C}$ & $682.6 \mathrm{AB}$ & $201.1 \mathrm{~B}$ & $69.29 \mathrm{~A}$ \\
\hline Treatments & $\mathrm{Na}$ & $\mathrm{Cl}$ & $\mathrm{Fe}$ & $\mathrm{Zn}$ & $\mathrm{Cu}$ & $\mathrm{Mn}$ \\
\hline$\left(\mathrm{F}_{0} \mathrm{C}_{1}\right)$ & $8.981 \mathrm{E}$ & $336.3 \mathrm{C}$ & $12.36 \mathrm{~A}$ & $4.548 \mathrm{~B}$ & $4.916 \mathrm{~B}$ & $6.179 \mathrm{~B}$ \\
\hline$\left(\mathrm{F}_{0} \mathrm{C}_{2}\right)$ & $16.10 \mathrm{AB}$ & $463.2 \mathrm{~A}$ & $11.34 \mathrm{ABC}$ & $4.911 \mathrm{AB}$ & $5.270 \mathrm{AB}$ & $7.115 \mathrm{~A}$ \\
\hline$\left(\mathrm{F}_{1} \mathrm{C}_{1}\right)$ & $12.31 \mathrm{CD}$ & $356.0 \mathrm{C}$ & $11.98 \mathrm{AB}$ & $4.164 \mathrm{C}$ & $4.889 \mathrm{~B}$ & $5.339 \mathrm{C}$ \\
\hline$\left(\mathrm{F}_{1} \mathrm{C}_{2}\right)$ & $18.16 \mathrm{~A}$ & $412.2 \mathrm{~B}$ & $10.63 \mathrm{CD}$ & $4.815 \mathrm{AB}$ & $5.249 \mathrm{AB}$ & $6.690 \mathrm{~A}$ \\
\hline$\left(\mathrm{F}_{2} \mathrm{C}_{1}\right)$ & $9.914 \mathrm{DE}$ & $356.8 \mathrm{C}$ & 11.13BCD & $4.636 \mathrm{AB}$ & $5.004 \mathrm{AB}$ & $5.902 B$ \\
\hline$\left(\mathrm{F}_{2} \mathrm{C}_{2}\right)$ & $14.03 \mathrm{BC}$ & 444.7AB & $9.993 \mathrm{D}$ & $5.015 \mathrm{~A}$ & $5.334 \mathrm{~A}$ & $6.843 \mathrm{~A}$ \\
\hline
\end{tabular}

Means, in each column, with at least one similar letters are not significantly different at the $5 \%$ probability level using Duncan multiple range test 
64

Tab. 7. The comparison of mean for the interaction effect between bacterium and cultivar on uptake of macro and micro elements and elements of $\mathrm{Na}$ and $\mathrm{Cl}\left(\mathrm{mg}\right.$ pot $\left.^{-1}\right)$

\begin{tabular}{|c|c|c|c|c|c|c|}
\hline Treatments & & $\mathrm{N}$ & $\mathrm{P}$ & $\mathrm{K}$ & $\mathrm{Ca}$ & $\mathrm{Mg}$ \\
\hline$\left(\mathrm{B}_{0} \mathrm{C}_{1}\right)$ & & $281.4 \mathrm{BC}$ & $28.25 \mathrm{C}$ & $551.7 \mathrm{D}$ & $214.6 \mathrm{AB}$ & $47.84 \mathrm{D}$ \\
\hline$\left(\mathrm{B}_{0} \mathrm{C}_{2}\right)$ & & $307.9 \mathrm{~A}$ & $29.05 \mathrm{ABC}$ & $766.6 \mathrm{~A}$ & $202.3 \mathrm{~B}$ & $80.45 \mathrm{~A}$ \\
\hline$\left(\mathrm{B}_{1} \mathrm{C}_{1}\right)$ & & $312.4 \mathrm{~A}$ & $32.20 \mathrm{~A}$ & $609.3 \mathrm{CD}$ & $201.5 \mathrm{~B}$ & $56.77 \mathrm{C}$ \\
\hline$\left(\mathrm{B}_{1} \mathrm{C}_{2}\right)$ & & $313.5 \mathrm{~A}$ & $30.32 \mathrm{ABC}$ & $729.9 \mathrm{AB}$ & $202.8 \mathrm{~B}$ & $72.13 \mathrm{~B}$ \\
\hline$\left(\mathrm{B}_{2} \mathrm{C}_{1}\right)$ & & $304.2 \mathrm{~A}$ & $31.76 \mathrm{AB}$ & $628 \mathrm{CD}$ & $199.2 \mathrm{~B}$ & $58.24 \mathrm{C}$ \\
\hline$\left(\mathrm{B}_{2} \mathrm{C}_{2}\right)$ & & $297 \mathrm{AB}$ & $28.66 \mathrm{BC}$ & $669.7 \mathrm{BC}$ & $204.7 \mathrm{AB}$ & $72.47 \mathrm{~B}$ \\
\hline$\left(\mathrm{B}_{3} \mathrm{C}_{1}\right)$ & & $298.1 \mathrm{AB}$ & $30.08 \mathrm{ABC}$ & $602.5 \mathrm{CD}$ & $219.4 \mathrm{~A}$ & $54.44 \mathrm{CD}$ \\
\hline$\left(\mathrm{B}_{3} \mathrm{C}_{2}\right)$ & & $273.7 \mathrm{C}$ & $27.34 \mathrm{C}$ & $580.5 \mathrm{D}$ & 208.4AB & $58.80 \mathrm{C}$ \\
\hline Treatments & $\mathrm{Na}$ & $\mathrm{Cl}$ & $\mathrm{Fe}$ & $\mathrm{Zn}$ & $\mathrm{Cu}$ & $\mathrm{Mn}$ \\
\hline$\left(\mathrm{B}_{0} \mathrm{C}_{1}\right)$ & $8.754 \mathrm{E}$ & $315.2 \mathrm{D}$ & $11.37 \mathrm{BC}$ & $4.002 \mathrm{C}$ & $4.338 \mathrm{C}$ & $5.493 \mathrm{E}$ \\
\hline$\left(\mathrm{B}_{0} \mathrm{C}_{2}\right)$ & $12.29 \mathrm{CD}$ & $491 \mathrm{~A}$ & $11.33 \mathrm{BC}$ & $4.801 \mathrm{AB}$ & $5.276 \mathrm{AB}$ & $7.548 \mathrm{~A}$ \\
\hline$\left(\mathrm{B}_{1} \mathrm{C}_{1}\right)$ & 10.12DE & $358.8 \mathrm{C}$ & $12.03 \mathrm{AB}$ & $4.48 \mathrm{~B}$ & $4.927 \mathrm{~B}$ & $6.261 \mathrm{CD}$ \\
\hline$\left(\mathrm{B}_{1} \mathrm{C}_{2}\right)$ & $20.66 \mathrm{~A}$ & $486.2 \mathrm{~A}$ & $10.85 \mathrm{BC}$ & $4.991 \mathrm{~A}$ & $5.536 \mathrm{~A}$ & $7.001 \mathrm{AB}$ \\
\hline$\left(\mathrm{B}_{2} \mathrm{C}_{1}\right)$ & $12.16 \mathrm{CD}$ & $377.6 \mathrm{C}$ & $12.97 \mathrm{~A}$ & $4.638 \mathrm{AB}$ & $5.270 \mathrm{AB}$ & $5.846 \mathrm{DE}$ \\
\hline$\left(\mathrm{B}_{2} \mathrm{C}_{2}\right)$ & $16.52 \mathrm{~B}$ & $423.2 \mathrm{~B}$ & $10.40 \mathrm{C}$ & $5.112 \mathrm{~A}$ & $5.303 \mathrm{AB}$ & $6.759 \mathrm{BC}$ \\
\hline$\left(\mathrm{B}_{3} \mathrm{C}_{1}\right)$ & $10.57 \mathrm{DE}$ & $347.3 \mathrm{CD}$ & $10.93 \mathrm{BC}$ & $4.678 \mathrm{AB}$ & $5.210 \mathrm{AB}$ & $5.626 \mathrm{DE}$ \\
\hline$\left(\mathrm{B}_{3} \mathrm{C}_{2}\right)$ & $14.91 \mathrm{BC}$ & $359.8 \mathrm{C}$ & $10.03 \mathrm{C}$ & $4.752 \mathrm{AB}$ & $5.023 \mathrm{~B}$ & $6.223 \mathrm{CD}$ \\
\hline
\end{tabular}

Means, in each column, with at least one similar letters are not significantly different at the $5 \%$ probability level using Duncan multiple range test

$\left.\mathrm{B}_{3} \mathrm{C}_{1}\right)$ increased $\mathrm{Zn}$ and $\mathrm{Cu}$ uptake by the plants compared with the control $\left(\mathrm{B}_{0} \mathrm{C}_{1}\right)$ (Tab. 7).

\section{Discussions and conclusions}

Soil salinity can cause lots of nutrition problems for the plants. The main reason for these nutrition problems can be related to the abundant presence of a special ion in soil solution like $\mathrm{Na}$ and $\mathrm{Cl}$. The abundance of these soluble ions can decrease the activity of other essential elements in the soil and lead to reduction in accessibility and uptake of elements by the plants. Lots of researchers reported that with increasing in soil salinity, the concentration of micro and macro elements in above ground parts of the plants as well as their roots will reduce (Feng et al., 2002; Al-Karaki, 2006; Giri et al., 2007).

AM fungi form symbiotic associations with the roots of most plant species, and they aid those plants in uptake of nutrients especially those immobile in soil like P (AlKaraki and Al-Raddad, 1997; Marschner and Dell, 1994; Cantrell and Linderman, 2001). However, the results of the present study showed that the inoculation of the soil by the Glomus etunicatum and Glomus intradices did not affected $\mathrm{P}$ uptake by the sunflower. One of the reasons for this observation was probably because of the small volume of soil. Usually the AM fungi hyphae show their effectiveness in a large volume of the soil and hence, into the limit environment of pots the hyphae could not work properly and did not their functions correctly. On the other hand the fungi had high population into the soil of the pots and therefore, the fungi could not show their role appropriately. The behavior of $\mathrm{Cl}$ uptake by the plants was al- most similar to the P uptake in the present study, which is in contrast with the findings by Graham and Syvertsen (1989). They reported that root colonization by AM fungi increased $\mathrm{Cl}$ uptake by the citrus plants in the saline condition. The AM fungi also did not affect the $\mathrm{K}$ uptake by the plants. It seams that the high concentration of $\mathrm{Na}$ in soil solution and fungi inability in reduction of $\mathrm{Na}$ uptake by the plants was its reason. Similar results were observed by the Poss et al. (1985) and Al-Karaki (2006) in tomato plants. They stated that K uptake was affected little by AM fungi root colonization in plants grown under saline conditions. In addition, in the present study, application of fungi inoculants reduced $\mathrm{Fe}$ and $\mathrm{Mn}$ uptake by the plants. Similarly, Pacovsky and Fuller (1998) showed that AM fungi reduced $\mathrm{Fe}$ concentration by the plants. This might indicate that $\mathrm{Fe}$ and $\mathrm{Mn}$ were retained in roots without being translocated to the above grounds parts of the plants and suggest that they might be retained in intraradical AM fungal hyphae or were compartmentalized in the root cell vacuoles (Cantrell and Linderman, 2001). Also, the lower $\mathrm{Fe}$ and $\mathrm{Mn}$ concentrations in AM plant tissues compared to nonAM plants might be explained by dilution effects due to growth enhancement by AM fungi colonization (Al-Karaki, 2000). In addition, in rhizosphere of AM plants, the population of $\mathrm{Mn}$ reduction bacteria will reduce and lead to deficit of exchangeable $\mathrm{Mn}$ in the soil (Sharma and Johri, 2002). However, different result was also reported by the Clark and Zeto (1996) in related to Fe uptake by corn plants. They pointed out that using of AM fungi significantly increased Fe uptake. 
Inoculation with PGPR containing ACC deaminase activity could be helpful in sustaining plant growth and development under stress conditions by reducing stressinduced ethylene production (Saleem et al., 2007). In the present study, the Pseudomonas fluorescens strain 4 could significantly increase the uptake of $\mathrm{K}$ and $\mathrm{P}$ by the plants. Similarly, Mayak et al. (2004) concluded that the uptake of $\mathrm{P}$ and $\mathrm{K}$ increased at the present of a PGPR in a salty environment at tomato plants. They also reported that the PGPR reduced the content of $\mathrm{Ca}, \mathrm{Mg}, \mathrm{K}$ and $\mathrm{S}$ in the salt environment; the content of $\mathrm{Na}$ was increased; and the content of $\mathrm{Ba}$ and $\mathrm{Fe}$ was unchanged. In the present study all of the bacterial inoculants (strains 4,9 and 12) significantly increased $\mathrm{Zn}$ and $\mathrm{Cu}$ compared with none inoculated plants. This improvement is probably because of the addition of root growth by the PGPRs that cause the root has more contact with the soil particles. Moreover, the PGPRs due to creation of special compounds may able to enhance the $\mathrm{Zn}$ and $\mathrm{Cu}$ uptake by the roots. The plants inoculated by PGPRs also had more $\mathrm{Na}$ uptake than to the noneinoculated plants while, the PGPRs did not increased the $\mathrm{K}, \mathrm{Ca}$ and $\mathrm{Mg}$ uptake by plants. On the other hand the Pseudomonas fluorescens strain 12 significantly decreased the uptake of $\mathrm{Cl}$ by the plants. This bacterium probably inhibits from $\mathrm{Cl}$ uptake by the roots or prevents from its translocation to the above ground parts. With lowering the $\mathrm{Cl}$ uptake probably uptake of other anions such as soleplate and nitrate by plants will increase and hence, the nutrition condition of the plant will increase.

\section{Acknowledgements}

We wish to thank University of Tehran for supporting field studies and samplings. We would like to gratefully thank all the members of the Soil Science Laboratory of Faculty of Agricultural Engineering and Technology of University of Tehran, for providing the facilities to carry out this work and for their suggestions.

\section{References}

Al-Karaki, G. N. (2006). Nursery inoculation of tomato with arbuscular mycorrhizal fungi and subsequent performance under irrigation with saline water. Scientia Horticulturae 109:1-7.

Al-Karaki, G. N. (2000). Growth of mycorrhizal tomato and mineral acquisition under salt stress. Mycorrhiza 10:51-54.

Al-Karaki, G. N. and A. Al-Raddad (1997). Effects of arbuscular mycorrhizal fungi and drought stress on growth and nutrient uptake of two wheat genotypes differing in drought resistance. Mycorrhiza 7:83-88.

Cantrell, I. C. and R. G. Linderman (2001). Preinoculation of lettuce and onion with VA mycorrhizal fungi reduces deleterious effects of soil salinity. Plant and Soil 233:269 281.

Cheng,Z.,E.ParkandB.R.Glick(2007).1-Aminocyclopropane- 1-carboxylate (ACC) deaminase from Pseudomonas putida UW4 facilitates the growth of canola in the presence of salt. Canadian Journal of Microbiology 53(7):912-918.

Clark, R. B. and S. K. Zeto (1996). Mineral acquisition by mycorrhizal maize grown on acid and alkaline soil. Soil Biology and Biochemistry 28:1405-1503.

Copeman, R. H., C. A. Martin and J. C. Stutz (1996). Tomato growth in response to salinity and mycorrhizal fungi from saline or nonsaline soils. HortScience 31:341-344.

Cottenie, A. (1980). Methods of Plant Analysis. In: Soil and Plant Testing. pp. 64-100. FAO Soils Bulletin 38/2.

Feng, G., F. S. Zhang, X. L. Li, C. Y. Tian, C. Tang and Z. Rengel (2002). Improved tolerance of maize plants to salt stress by arbuscular mycorrhiza is related to higher accumulation of soluble sugars in roots. Mycorrhiza 12:185-190.

Gamalero, E., L. Fracchia, M. Cavaletto, J. Garbaye, P. Frey-Klett, G. C. Varese and M. G. Martinotti (2003). Characterization of functional traits of two fluorescent pseudomonads isolated from basidiomes of ectomycorrhizal fungi. Soil Biology \& Biochemistry 35:55-65.

Giri, B., R. Kapoor and K. G. Mukerji (2007). Improved tolerance of Acacia nilotica to salt stress by arbuscular mycorrhiza, Glomus Fasciculatum may be partly related to elevated $\mathrm{K} / \mathrm{Na}$ ratios in root and shoot tissues. Microbial Ecology.54:753-760.

Glick, B. R., D. M. Penrose and J. Li (1998). A model for the lowering of plant ethylene concentrations by plant growthpromoting bacteria. Journal of Theoretical Biology 190:6368.

Graham, J. H. and A. Syvertsen (1989). Vesicular-Arbuscular Mycorrhiza increase chloride concentration in citrus seedling. New Phytologist 113:29-36.

Hamdia, M. A., M. A. K. Shaddad and M. M. Doaa (2004). Mechanisms of salt tolerance and interactive effects of Azospirillum brasilense inoculation on maize cultivars grown under salt stress conditions. Plant Growth Regulation 44:165-174.

Hipp, B. W. and G. W. langdal (1971). Use of a solid-state chloride electrode for chloride determination in soil extracts. Soil Science and Plant Analysis 2:237-240.

Kafi, M. and A. M. Damghani (2000). The mechanisms of plant resistance to salt stress. Mashhad Ferdosi University Press, Mashhad, Iran (In Persian).

Marschner, H. and B. Dell (1994). Nutrient uptake in mycorrhizal symbiosis. Plant and Soil 159:89-102.

Mayak, S., T. Tirosh and B. R. Glick (2004). Plant growthpromoting bacteria confer resistance in tomato plants to salt stress. Plant Physiology and Biochemistry 42:565-572.

Mirmahammadi-Meybodi, S. and B. Ghareyazi (2002). Physiological aspects of salt stress in plants. Isfahan University Press, Isfahan, Iran (In Persian).

Nadeem, S. M., I. Hussain, M. Naveed, H. N. Ashgar, Z. A. Zahir and M. Arshad (2006a). Performance of plant growth 
66

promoting rhizobacteria containing ACC-deaminase activity for improving growth of maize under salt-stressed conditions. Pakistan Journal of Agricultural Sciences 43:114-121.

Nadeem, S. M., Z. A. Zahir, M. Naveed, M. Arshad and S. M. Shahzad (2006b). Variation in growth and ion uptake of maize due to inoculation with plant growth promoting rhizobacteria under salt stress. Plant, Soil and Environment 25:78-84.

Pacovsky, R. S. and G. Fuller (1998). Mineral and lipid composition of Glycine-Glomuse-Bradyrhizobium symbiosis. Physiologica plantarum 72:733-746.

Penrose, M. and B. R. Glick (2003). Methods for isolating and characterizing Acc deaminase-containing Plant GrowthPromoting Rhizobacteria. Plant Physiology 118:10-15.

Poss, J. A., E. Pond, J. A. Menge and W. M. Harrell (1985). Effect of salinity on mycorrhizal onion and tomato in soil with and without additional phosphate. Plant and Soil 88:307-319.

Russo, A., C. Felici, A. Toffanin, M. Götz, C. Collados, J. M. Barea, Y. Moënne-Loccoz, K. Smalla, J. Vanderleyden and M. Nuti (2005). Effect of Azospirillum inoculants on arbuscular mycorrhiza establishment in wheat and maize plants. Biology and Fertility of Soils 41:301-309.
Saleem, M., M. Arshad, S. Hussain and A. S. Bhatti (2007). Perspective of plant growth promoting rhizobacteria (PGPR) containing ACC deaminase in stress agriculture. Journal of Industrial Microbiology and Biotechnology 34:635-648.

Sannazzaro, A. I., M. Echeverria, E. O. Alberto, O. A. Ruiz and A. B. Menendez (2007). Modulation of polyamine balance in Lotus glaber by salinity and arbuscular mycorrhiza. Plant Physiology and Biochemistry 45:39-46.

Sannazzaro, A. I., O. A. Ruiz, E. O. Alberto and A. B. Menendez (2006). Alleviation of salt stress in Lotus glaber by Glomus intraradices. Plant and Soil 285:279-287.

Saravanakumar, D. and R. Samiyappan (2007). ACC deaminase from Pseudomonas Xuorescens mediated saline resistance in groundnut (Arachis hypogea) plants. Journal of Applied Microbiology 102:1283-1292.

Sharma, A. K. and B. N. Johri (2002). Arbuscular Mycorrhiza, Interactions in Plant, Rhizosphere and Soil. Oxford and IBH Publishing. New Dehli, India.

Yano-Melo, A. M., O. J. Saggin and L. C. Maia (2003). Tolerance of mycorrhized banana (Musa sp. cv. Pacovan) plantlets to saline stress. Agriculture, Ecosystems and Environment. 95:343-348. 